\title{
Isolated growth hormone deficiency
}

\section{Two families with autosomal dominant inheritance}

\author{
E. M. E. POSKITT and P. H. W. RAYNER \\ From the Institute of Child Health, Francis Road, Birmingham
}

\begin{abstract}
Poskitt, E. M. E., and Rayner, P. H. W. (1974). Archives of Disease in Childhood, 49, 55. Isolated growth hormone deficiency: two families with autosomal dominant inheritance. Two families, each with a father and a son affected by isolated growth hormone deficiency, are described. The inheritance in these cases seems to be due to an autosomal dominant gene. Isolated growth hormone deficiency appears to be a heterogeneous condition.
\end{abstract}

Isolated deficiency of growth hormone $(\mathrm{GH})$ with sexual maturation has been described frequently (Nadler, Neumann, and Gershberg, 1963; Brasel et al., 1965; Goodman, Grumbach, and Kaplan, 1968; Tanner et al., 1971). Though of varied aetiology, the condition may be familial. Tanner (1972) has recently stated that $15 \%$ of children with isolated GH deficiency not due to a tumour have similarly affected sibs, though at this hospital there are no affected sibs among 30 cases of isolated $\mathrm{GH}$ deficiency. The reported familial cases usually show an autosomal recessive pattern of inheritance (Trystad and Seip, 1964; Pertzelan, Adam, and Laron, 1968). However, two GH-deficient parents described by Rimoin, Merimee, and McKusick (1966) have had both dwarfed and normal children. Such a family could be explained by autosomal dominant inheritance, and it does seem that dominantly transmitted GH deficiency occurs (Sheikholislam and Stempfel, 1972). Two families are described which may illustrate this condition.

\section{Methods}

Glucose $1 \cdot 75 \mathrm{~g} / \mathrm{kg}$ body weight was given orally for prolonged glucose tolerance testing, and glucose and growth hormone levels were estimated at $0,30,60,120$, 240 , and 300 minutes. A dose of soluble insulin $0 \cdot 1$ unit $/ \mathrm{kg}$ was given intravenously during insulin sensitivity testing and blood samples for glucose and growth hormone were obtained at $0,10,20,30,40,60,80$, and 100 minutes. Glucose was estimated by a semiautomated method (Discombe, 1963). Growth hormone estimation was carried out by a modification of the double-antibody immunoassay (Hartog et al., 1964).

Received 13 July 1973.
Results are recorded in IU (MRC first International reference preparation for radioimmunoassay).

\section{Case reports}

Family B.

Case 1. A male was born at term of a normal delivery in 1943. His parents were unrelated and there was no family history of short stature. Birthweight was $3150 \mathrm{~g}$. He developed normally except that by the age of 2 he was noticeably short. Thyroid extract was given for 2 years without effect on his growth. When aged $7 \frac{1}{2}$ his height was $92.5 \mathrm{~cm}$, a height age of 3 years, and his weight was $13.6 \mathrm{~kg}$, a weight age of $2 \frac{1}{2}$ years. He had small facial features with prominent forehead, but body proportions were otherwise normal. Bone age was $5 \frac{1}{2}$ years with no epiphyseal dysgenesis. Serum cholesterol was 281 $\mathrm{mg} / 100 \mathrm{ml}$. Urinary ketosteroids were $3.9 \mathrm{mg} / 24$ hours. A further 3-month course of thyroid had no effect on growth, skeletal maturation, or serum cholesterol and he was given methyl testosterone $20 \mathrm{mg}$ daily to stimulate growth. This produced acceleration of growth and bony maturation so that at a chronological age of 9.3 years his height was $109 \mathrm{~cm}$ (height age 5 years) and bone age was 9 years. His clinical attendances were infrequent; but in 1959, when aged $16 \frac{1}{2}$, he was admitted to hospital with asthma and his pituitary status was reassessed. His height was $133 \mathrm{~cm}$, equivalent to the 50th centile at 9 years and his weight was $28.6 \mathrm{~kg}$. He showed signs of pubertal development with sparse facial hair, moderate pubic hair, and increased testicular size. 17 keto- and hydroxysteroid excretions were 5.4 $\mathrm{mg}$ and $8 \cdot 2 \mathrm{mg} / 24$ hours, increasing to $12 \mathrm{mg} / 24$ hours and $55 \mathrm{mg} / 24$ hours after 40 IU ACTH intramuscularly. Methyl testosterone was started again and he received in addition a course of prednisone for his asthma. Over the next 3 years he grew $7 \mathrm{~cm}$, reaching a final adult height of $140 \mathrm{~cm}$ (Fig. 1). Pubertal development continued with further increase in testicular size. In 1963 , when aged 20, he married. His wife was $150 \mathrm{~cm}$ 


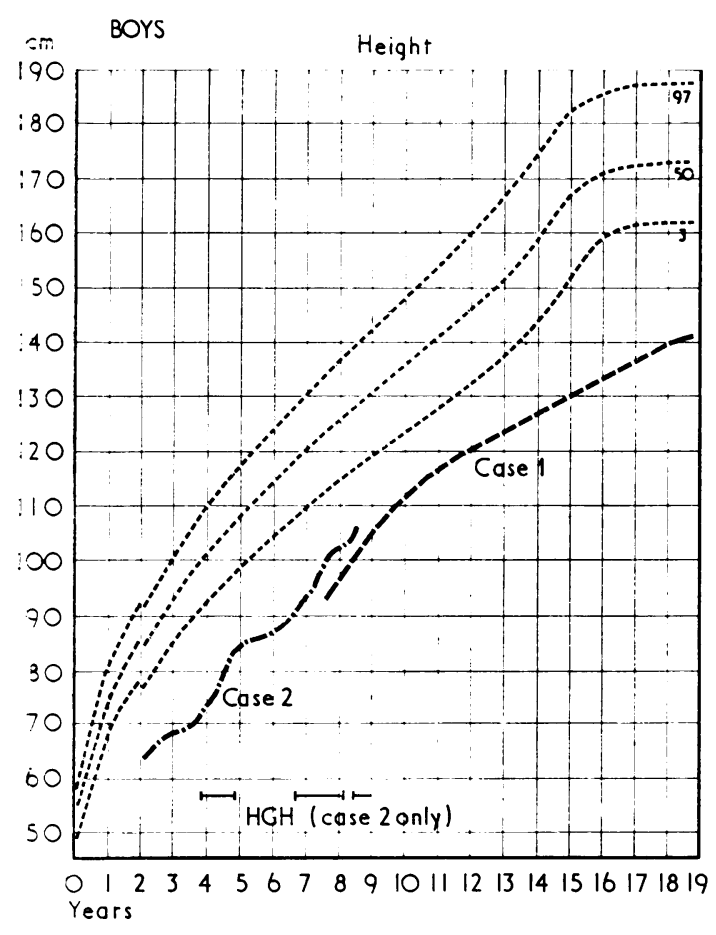

Fig. 1.-Linear growth curves of Cases 1 and 2.

tall. A year later a son, Case 2 below, was born. Then a girl was born in 1966, birthweight $3.7 \mathrm{~kg}$, and a second son was born in 1971, birthweight $3 \cdot 28 \mathrm{~kg}$. Both the latter children showed normal growth and GH response during a prolonged glucose tolerance test. Subsequent to the recognition of GH deficiency in Case 2, a prolonged glucose tolerance test was performed on Case 1. There was complete failure of $\mathrm{GH}$ production, despite blood sugar levels of $34 \mathrm{mg} / 100 \mathrm{ml}$ at 4 hours, suggesting GH deficiency in Case 1 as well (Table I).

\section{TABLE I}

Growth hormone response to prolonged glucose tolerance testing $(1 \cdot 75 \mathrm{~g} / \mathrm{kg}$ body weight $)$

\begin{tabular}{|c|c|c|c|c|}
\hline \multirow{2}{*}{$\begin{array}{l}\text { Time } \\
\text { (min) }\end{array}$} & \multicolumn{2}{|c|}{ Case 1} & \multicolumn{2}{|c|}{ Case 2} \\
\hline & $\begin{array}{c}\text { Glucose } \\
(\mathrm{mg} / 100 \mathrm{ml})\end{array}$ & $\begin{array}{c}\text { Growth } \\
\text { hormone } \\
(\mu \mathrm{U} / \mathrm{ml})\end{array}$ & $\begin{array}{c}\text { Glucose } \\
(\mathrm{mg} / 100 \mathrm{ml})\end{array}$ & $\begin{array}{l}\text { Growth } \\
\text { hormone } \\
(\mu \mathrm{U} / \mathrm{ml})\end{array}$ \\
\hline $\begin{array}{r}0 \\
30 \\
60 \\
120 \\
180 \\
240 \\
300\end{array}$ & $\begin{array}{r}55 \\
117 \\
106 \\
87 \\
43 \\
34 \\
51\end{array}$ & $\begin{array}{l}1 \\
1 \\
1 \\
0 \\
0 \\
0 \\
0\end{array}$ & $\begin{array}{l}15 \\
22 \\
74 \\
56 \\
18 \\
19 \\
18\end{array}$ & $\begin{array}{l}1 \\
1 \\
1 \\
1 \\
1 \\
1 \\
1\end{array}$ \\
\hline
\end{tabular}

Case 2. A male, born in September 1964, was the $\stackrel{\rho}{=}$ first-born son of Case 1. He was a term forceps delivery, birthweight $3200 \mathrm{~g}$. There were no resuscitative $\vec{F}$ difficulties, and initially he appeared to thrive. His $\stackrel{\leftrightarrow}{\mathscr{S}}$ developmental milestones were normal, but by the age of 0 6 months small size was apparent. In addition, he was 흠 frequently very drowsy before breakfast, probably due to $\frac{\bar{\sigma}}{\bar{\rho}}$. early morning hypoglycaemia. By 2 years of age he was $\overparen{\nabla}$ only $6.60 \mathrm{~kg}$ (weight age 4 months) and $67 \mathrm{~cm}$ tall (height $\cong$ age 5 months). His hands and feet were small and his of face was infantile with noticeable wrinkling of the $\overrightarrow{0}$ forehead. Skull circumference was $45 \mathrm{~cm}$, equivalent to the 50th centile for 11 months. Neither testis could be $\vec{\omega}$ felt in the hypoplastic scrotum, but there were no other $\stackrel{\sigma}{\sigma}$ abnormalities. Skeletal maturation was equivalent to $15 \%$ months. Skull $x$-ray showed a normal pituitary fossa. Protein-bound iodide was $5.7 \mu \mathrm{g} / 100 \mathrm{ml}$ and serum $\overrightarrow{0}$ cholesterol $189 \mathrm{mg} / 100 \mathrm{ml}$. There was normal increase in blood cortisol after 40 IU ACTH intramuscularly, but in a prolonged glucose tolerance test showed a fasting blood $\mathrm{G}$ glucose of $15 \mathrm{mg} / 100 \mathrm{ml}$ and no measurable $\mathrm{GH}$ 을 production despite hypoglycaemia of $18 \mathrm{mg} / 100 \mathrm{ml}$ at 3 and 5 hours after glucose (Table I). He appeared to be a definite case of GH deficiency. Growth continued slowly (Fig. 1), and from May 1968 he received a oneyear course of twice-weekly injections of $10 \mathrm{mg}$ human growth hormone (Raben). In January 1971 he began a $\vec{\varphi}$ further course of $\mathrm{GH}$ and has continued this apart from a break of 4 months in 1972. While on GH he has had marked increase in growth velocity (Fig. 2), though

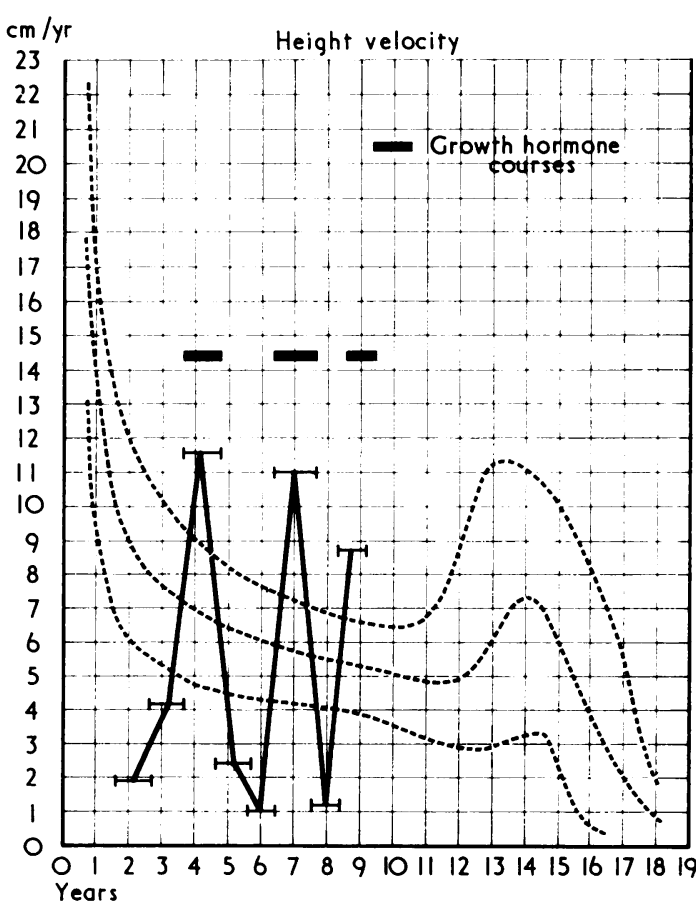

Fig. 2.-Case 2. Annual height increment in $\mathrm{cm} /$ year. 
between the courses growth virtually ceases. Such a pattern is typical of the GH-deficient child during treatment.

\section{Family G.}

Case 3. A male of normal birthweight was born in 1925, the second son of tall, unrelated parents. His only sib is over $180 \mathrm{~cm}$ tall and there is no family history of short stature. He was breast fed and initially thrived, though he was described as very round and chubby. Short stature was marked by 3 years of age. By $12 \frac{1}{2}$ he was $120 \mathrm{~cm}$ tall, $15 \mathrm{~cm}$ below the $3 \mathrm{rd}$ centile for his age and a mean height for 7 years of age. He was obese with an infantile face and small hands and feet. However, his mental development was better than average as he won a scholarship to grammar school. $X$-rays at this time showed no bone disorder to account for short stature and bone maturation was not recorded. He was diagnosed a pituitary dwarf and treated with thyroid $15 \mathrm{mg}$ twice daily and twice-weekly injections of Antuitrin G (a crude pituitary extract). Antuitrin $G$ was continued more or less without a break for the next 8 years. This treatment had no apparent effect on his growth, which continued well below the 3 rd centile for age (Fig. 3). At $16 \frac{1}{2}$ his voice was breaking and his growth showed a slight pubertal spurt. At 20, $x$-rays of long bones suggested epiphyseal fusion and he had reached his final height of $147 \mathrm{~cm}$. Some years later he married a woman of 163 $\mathrm{cm}$ in height from a tall family. When he was aged 32

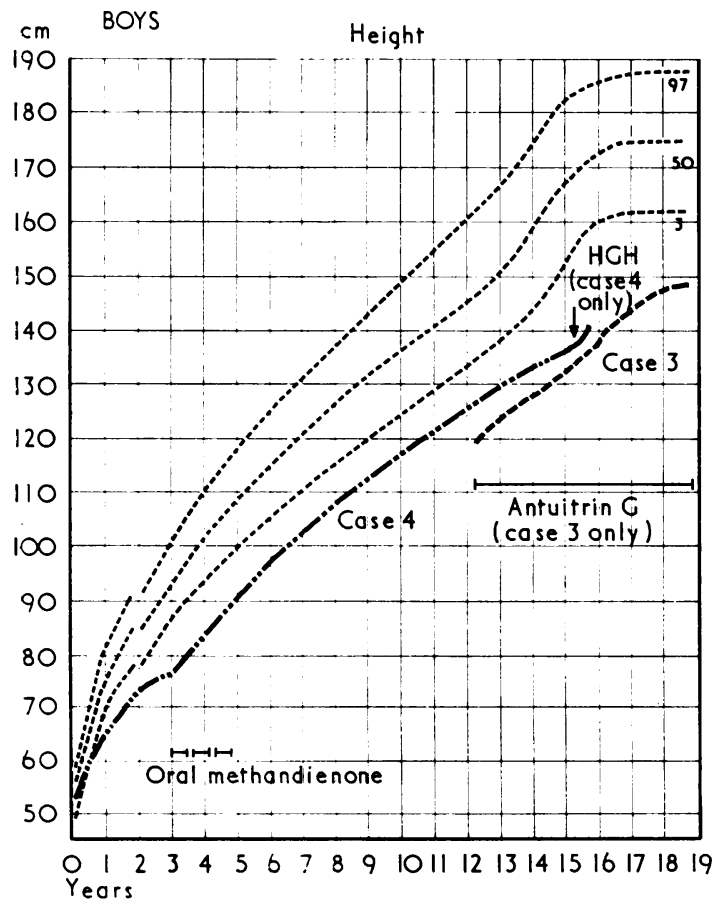

FIG. 3.-Linear growth curves of Cases 3 and 4. his first child, Case 4, was born. Since then he has had 2 daughters, both of normal stature.

In 1961 urinary hydroxycorticosteroid excretion was $11 \mathrm{mg} / 24$ hours. In 1970, an insulin sensitivity test produced no GH response (Table II), thus supporting

TABLE II

Growth hormone response to insulin-induced hypoglycaemia

\begin{tabular}{r|c|c|c|c}
\hline \multirow{2}{*}{$\begin{array}{c}\text { Time } \\
(\mathrm{min})\end{array}$} & \multicolumn{2}{|c|}{ Case 3 } & \multicolumn{2}{|c}{ Case 4 } \\
\cline { 2 - 5 } & $\begin{array}{c}\text { Glucose } \\
(\mathrm{mg} / 100 \mathrm{ml})\end{array}$ & $\begin{array}{c}\text { Growth } \\
\text { hormone } \\
(\mu \mathrm{U} / \mathrm{ml})\end{array}$ & $\begin{array}{c}\text { Glucose } \\
(\mathrm{mg} / 100 \mathrm{ml})\end{array}$ & $\begin{array}{c}\text { Growth } \\
\text { hormone } \\
(\mu \mathrm{U} / \mathrm{ml})\end{array}$ \\
\hline 0 & 65 & 1 & 60 & 4 \\
20 & 19 & 0 & 31 & 3 \\
30 & 12 & 1 & 24 & 2 \\
40 & 22 & 1 & 49 & 4 \\
60 & 29 & 0 & 59 & 3 \\
80 & 45 & 0 & & \\
100 & 52 & 0 & & \\
\hline
\end{tabular}

the clinical diagnosis of isolated growth hormone deficiency.

Case 4. The son of Case 3 was born in 1957 by lower segment caesarean section because pregnancy was complicated by an ovarian cyst. Birthweight was $3640 \mathrm{~g}$ and length $53 \mathrm{~cm}$. At the age of 1 year he was short, with a length of $63 \mathrm{~cm}$. By 3 years of age his height was $77.5 \mathrm{~cm}$, a height age for 15 months, and bone age was equivalent to 30 months. He had the small features and prominent forehead of $\mathrm{GH}$ deficiency. He was treated with $10 \mathrm{mg}$ methandienone daily between March and July 1960 . Courses of $5 \mathrm{mg}$ /day and $2.5 \mathrm{mg}$ /day were given for 3 months from January and May 1961. This treatment produced growth of $9.5 \mathrm{~cm}$ between 3 and 4 years of age but also bony maturation, so that at a chronological age of 5 years his bone age had advanced to 6 years. In 1963 a further dose of methandienone produced an annual growth rate of $7 \mathrm{~cm}$. After this he grew slowly, falling further from the 3 rd centile for age (Fig. 3). At age 12 years 2 months his height was 127 $\mathrm{cm}$ (height age 8 years), and his weight of $36.6 \mathrm{~kg}$ was at about the 50th centile for age. He had marked truncal obesity with small hands and feet and immature body proportions. Serum cholesterol was $222 \mathrm{mg} / 100 \mathrm{ml}$, protein-bound iodide $5 \cdot 1 \mu \mathrm{g} / 100 \mathrm{ml}$. There was no significant growth hormone response to prolonged glucose tolerance test or insulin sensitivity test (Table II). Plasma cortisol levels were normal. Now, at the age of $15 \frac{1}{2}$ years, he shows no signs of puberty, bone age is equivalent to $12 \frac{1}{2}$ years and he has started treatment with human growth hormone.

\section{Discussion}

The 4 cases described have characteristic clinical and biochemical features of GH deficiency. Such children are usually of normal birthweight but short 
stature is noticed in infancy. Failure to gain weight is less marked than failure to grow in height, though anorexia in early life may produce low weight, as in Cases 1 and 2. Episodes of spontaneous or postprandial hypoglycaemia may complicate early childhood. In later childhood, obesity is a problem. Certain clinical features also suggest $\mathrm{GH}$ deficiency, notably normal body proportions with small hands and feet but immature facies, prominent forehead with markedly soft wrinkled skin, and normal skull size. In boys there may be hypodevelopment of genitalia and cryptorchidism.

The biochemical diagnosis of GH deficiency lies in showing the absence of $\mathrm{GH}$ secretion in response to a challenge, such as hypoglycaemia produced by intravenous insulin or as a result of a prolonged glucose tolerance test. All 4 cases described show negligible $\mathrm{GH}$ response to profound hypoglycaemia, strongly suggesting $\mathrm{GH}$ deficiency.

GH deficiency may be associated with deficiency of other anterior pituitary hormones. The cases we described have no evidence of adrenocorticotrophic or thyrotrophic deficiency. More frequently gonadotrophin deficiency accompanies GH deficiency. However, Cases 1 and 3 have shown adequate gonadotrophin secretion by their fertility. Case 2 is still too young for gonadotrophin secretion to be significant. Case 4 , at $15 \frac{1}{2}$, might be expected to show signs of puberty with high gonadotrophin excretion, but puberty is delayed in untreated GH-deficient patients who ultimately become sexually mature (Goodman et al., 1968). Bone maturity is a more reliable indication of the appropriate time of onset of puberty than chronological age (Tanner, 1972). Thus, Case 4 can still be expected to develop spontaneous puberty as his present bone age at $12 \frac{1}{2}$ is only just within the pubertal range.

The pattern of inheritance in these two families does not readily fit into an autosomal recessive pattern. There is no family history of short stature other than in the family of the wife of Case 1 in which shortness involves all members and constitutional short stature seems more likely a diagnosis than any pathological dwarfing. She herself has normal GH secretion.

All 4 cases described are males, so the possibility of a recessive but sex-linked condition should be considered. However, the pattern of both father and son affected is not that of an X-chromosome linked condition. Moreover, there are no other short males in the families and Case 1 has a second son of normal stature and growth hormone secretion. This excludes the possibility of a sex-linked condition. Isolated growth hormone deficiency is, however, more common in males than females (Tanner, 1972), and it may be that there is some sex-limiting factor operating.

The most likely pattern of inheritance in the 2 families described remains that of autosomal dominant isolated GH deficiency. Rimoin and Schimke (1971) classify this condition as type II isolated $\mathrm{GH}$ deficiency. They suggested that these cases are distinguishable from autosomal recessive (type I) isolated GH deficiency by the absence of the soft wrinkled skin usually a feature of GH-deficient adults. They also characterize type II deficiency by lack of both hypoglycaemic attacks and insulin hypersensitivity. These patients have abnormally high insulin secretion to a glucose load in contrast to the decreased secretion of type I and nonfamilial GH deficiency (Merimee et al., 1968).

However, Sheikholislam and Stempfel (1972) did not confirm these findings in their cases of dominantly inherited $\mathrm{GH}$ deficiency. Our adult patients, and to a lesser extent their children, have typical wrinkled facial skin. Unfortunately, insulin secretion has not been studied, but Case 2 had fasting hypoglycaemia and early morning hypoglycaemic episodes. Cases 3 and 4 had profound hypoglycaemia in response to exogenous insulin. Thus it seems our cases do not have the specific features of type II deficiency either. Deficiency of pituitary GH may result from failure of production of GH-releasing factor in the hypothalamus and this could be the genetic abnormality in our cases. However, the functional defect and clinical effect would be identical with primary GH deficiency. Merimee et al. (1968) suggested that the unusual features of their type II patients may be due to production of an altered $\mathrm{GH}$ molecule, undetectable by immunoassay yet with selective biological activity. If this is so, a group of patients with dominantly inherited growth hormone deficiency may include examples of several inherited disorders of the neuro-hypophyseal-pituitary axis. This could explain clinical and biochemical variation within the group. Further investigations of the $\mathrm{GH}$-releasing pathway and other methods of GH assay may be required before the apparent heterogeneity in this condition can be resolved.

We are indebted to Drs. B. Rudd and J. Williams, of the Institute of Child Health, for hormonal estimations in these cases.

\section{REFERENCES}

Brasel, J. A., Wright, J. C., Wilkins, L., and Blizzard, R. M. (1965). An evaluation of seventy-five patients with hypopituitarism beginning in childhood. American fournal of Medicine, 38, 484. Discombe, G. (1963). An inexpensive method for the estimation of true glucose in blood and other fluids by the autoanalyzer. Fournal of Clinical Pathology, 16, 170. 
Goodman, H. G., Grumbach, M. M., and Kaplan, S. L. (1968). Growth and growth hormone. II. A comparison of isolated growth-hormone deficiency and multiple pituitary hormone deficiencies in thirty-five patients with idiopathic hypopituitary dwarfism. New England fournal of Medicine, 278, 57.

Hartog, M., Gaafar, M. A., Meisser, B., and Fraser, R. (1964). Immunoassay of serum growth hormone in acromegalic patients. British Medical fournal, 2, 1229.

Merimee, T. J., Rabinowitz, D., Rimoin, D. L., and McKusick, V. A. (1968). Isolated human growth hormone deficiency. III. Insulin secretion in sexual ateliotic dwarfism. Metabolism, 17, 1005.

Nadler, H. L., Neumann, L. L., and Gershberg, H. (1963). Hypoglycaemia, growth retardation, and probable isolated growth hormone deficiency in a one-year-old child. Fournal of Pediatrics, 63, 977.

Pertzelan, A., Adam, A., and Laron, Z. (1968). Genetic aspects of pituitary dwarfism due to absence or biological inactivity of growth hormone. Israel fournal of Medical Sciences, 4, 895.

Rimoin, D. L., Merimee, T. J., and McKusick, V. A. (1966). Growth-hormone deficiency in man: an isolated, recessively inherited defect. Science, 152, 1635.
Rimoin, D. L., and Schimke, R. N. (1971). The anterior pituitary. In Genetic Disorders of the Endocrine Glands, p. 38 . Mosby, St. Louis; Kimpton, London.

Sheikholislam, B. M., and Stempfel, R. S., Jr. (1972). Hereditary isolated somatotrophin deficiency: effects of human growth hormone administration. Pediatrics, 49, 362.

Tanner, J. M. (1972). Human growth hormone. Nature, 237, 433.

Tanner, J. M., Whitehouse, R. H., Hughes, P. C. R., and Vince, F. P. (1971). Effect of human growth hormone treatment for 1 to 7 years on growth of 100 children with growth hormone deficiency, low birth weight, inherited smallness, Turner's syndrome, and other complaints. Archives of Disease in Childhood, 46, 745.

Trystad, O., and Seip, M. (1964). Hereditary pituitary dwarfism treated with human growth hormone. Acta Paediatrica, 53, 527.

Correspondence to Dr. P. H. W. Rayner, Institute of Child Health, Francis Road, Birmingham B16 8ET. 